\title{
Annual Report, Mâterials Science Branch, FY 1992
}

Materials Science Branch

S. Padilla, Editor

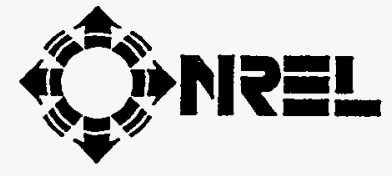

National Renewable Energy Laboratory 1617 Cole Boulevard Golden, Colorado 80401-3393 A national laboratory operated for the U.S. Department of Energy under contract No. DE-AC02-83CH10093

Prepared under Task No. PV314001

October 1993 


\section{NOTICE}

NOTICE: This report was prepared as an account of work sponsored by an agency of the United States government. Neither the United States government nor any agency thereof, nor any of their employees, makes any warranty, express or implied, or assumes any legal liability or responsibility for the accuracy, completeness, or usefulness of any information, apparatus, product, or process disclosed, or represents that its use would not infringe privately owned rights. Reference herein to any specific commercial product, process, or service by trade name, trademark, manufacturer, or otherwise does not necessarily constitute or imply its endorsement, recommendation, or favoring by the United States government or any agency thereof. The views and opinions of authors expressed herein do not necessarily state or reflect those of the United States govemment or any agency thereof.

Printed in the United States of America Available from:

National Technical Information Service

U.S. Department of Commerce

5285 Port Royal Road

Springfield, VA 22161

Price: Microfiche $\mathrm{AO} 1$

Printed Copy $\mathrm{AOZ}_{\text {: }}$;

Codes are used for pricing all publications. The code is determined by the number of pages in the publication. Information pertaining to the pricing codes can be found in the current issue of the following publications which are generally available in most libraries: Energy Research Abstracts (ERA); Government Reports Announcements and Index (GRA and I); Scientific and Technical Abstract Reports (STAR); and publication NTIS-PR-360 available from NTIS at the above address. 


\section{DISCLAIMER}

Portions of this document may be illegible electronic image products. Images are produced from the best available original document. 


\section{TABLE OF CONTENTS}

\section{MATERIALS SCIENCE BRANCH}

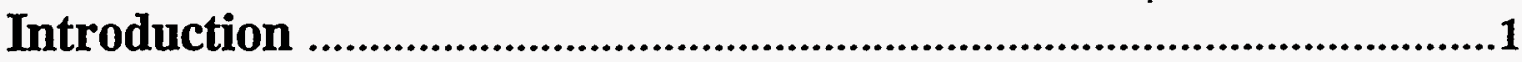

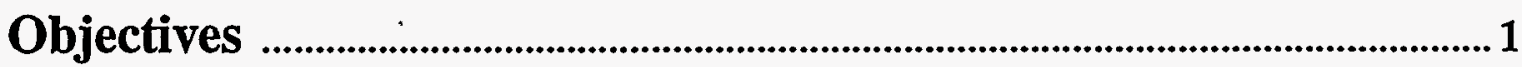

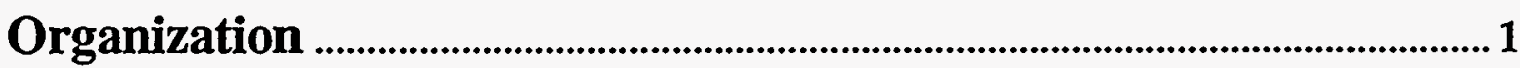

Program Areas and Key Accomplishments................................................... 1

(In-House Research)

- Crystal Growth Research

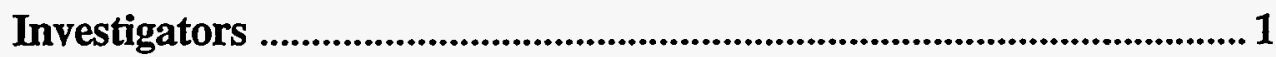

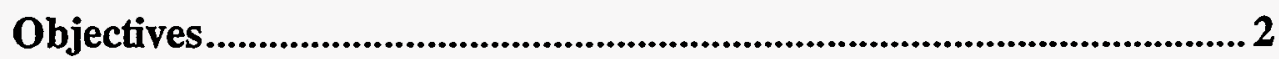

Key Accomplishments............................................................................... 2

Publications...................................................................................................

- Amorphous Silicon Research

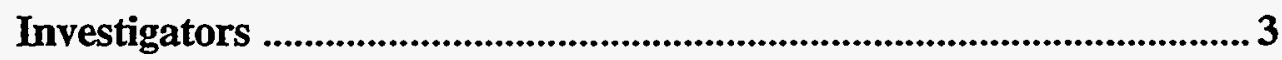

Objectives........................................................................................................

Key Accomplishments................................................................................. 3

Publications..................................................................................................... 4 


\section{TABLE OF CONTENTS}

\section{(In-House Research)}

- III-V High-Efficiency Photovoltaic Cells

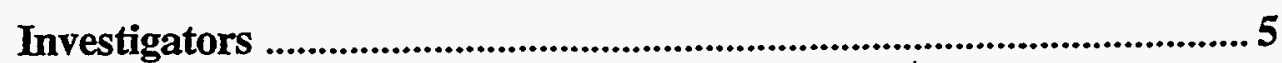

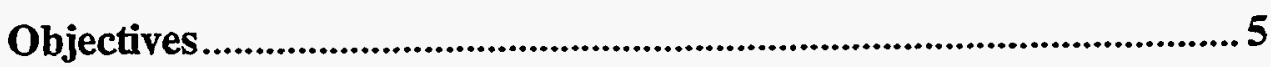

Key Accomplishments...............................................................................

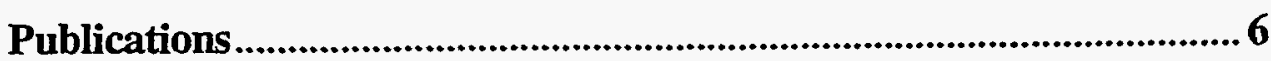

- Solid State Theory

Investigators .........................................................................................6

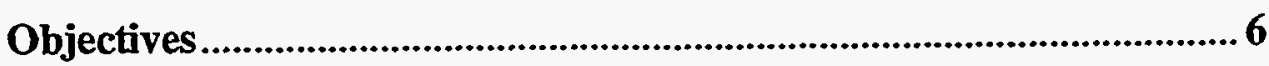

Key Accomplishments......................................................................6

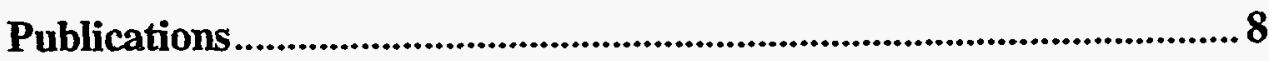

- Solid State Spectroscopy

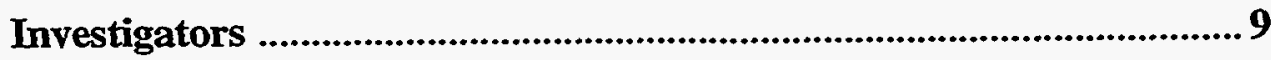

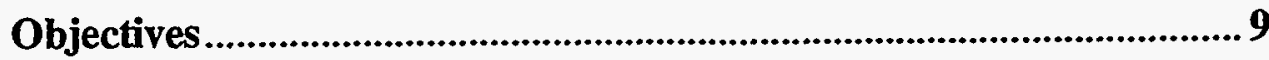

Key Accomplishments.............................................................................9

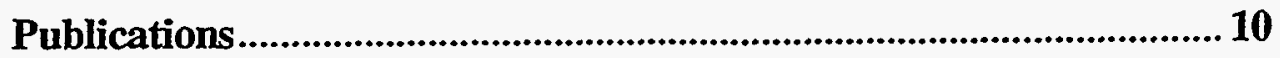

- Program Management

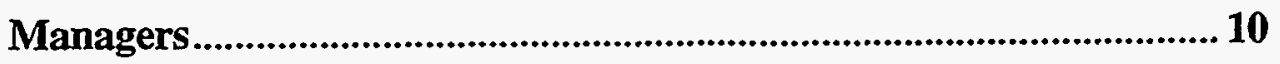

Objectives.............................................................................................. 10

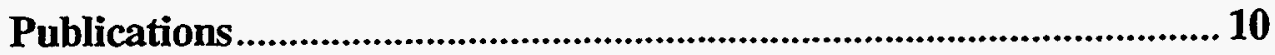




\section{Introduction}

This summary annual report covers the research and development in the Materials Science Branch of the Basic Sciences Division at the National Renewable Energy Laboratory (NREL), during the period of October 1, 1991, to September 30, 1992.

\section{Objectives}

The branch carries out fundamental and applied research on materials with potential application to photovoltaics (PV) or other renewable energy technologies. Specifically, its objectives are

1. To define and carry out materials science research that is consistent with the Department of Energy's (DOE) goals

2. To relate the results of renewable energy technologies through appropriate device research within the branch, or through interactions with other laboratory, academic, or industrial organizations

3. To identify research needs and develop, evaluate, and transfer a coherent base of scientific knowledge and technology to the public and industrial sectors, so that rational decisions can be made on the relevance of different renewable energy technologies for cost-effective power generation.

\section{Organization}

To meet these objectives, in-house research activities within the branch are structured into the following areas:

- Crystal Growth Research

- Amorphous Silicon Research

- III-V High-Efficiency Photovoltaic Cells

- Solid-State Theory

- Solid-State Spectroscopy

Our goal is to closely integrate these areas with one another and with the related activities in other branches and with program subcontractors.

The work is funded primarily by $D O E$, from both the Office of Conservation and
Renewable Energy (through the Office of Utility Technologies - the PV Program) and the Office of Energy Research/Basic Energy Sciences (through the Division of Material Sciences). There is also funding from the Director's Discretionary Fund (DDF) and several Work for Others programs with industry.

The branch is also responsible for program management, including the following:

- Crystalline Materials and Advanced Concepts (PV Program)

- Energy Related Aerospace Programs

- University Programs

- New Ideas Programs

In fiscal year (FY) 1992, the branch staff was composed of 31 full-time researchers, 10 visiting scientists and students, 1 branch manager, 2 administrative assistants, 1 senior project manager, and 1 project coordinator.

\section{Program Areas and Key Accomplishments}

During FY 1992, the members of the branch made major contributions to various technologies through fundamental studies and applied research and development. The key accomplishments are stated below and are followed by the FY 1992 publications list for each program area within the branch.

\section{Crystal Growth Research}

\section{Investigators}

T. F. Ciszek, Principal Scientist

Y. S. Tsuo, Senior Scientist

C. R. Schwerdtfeger, Staff Scientist

R. Burrows, Master Technician

J. Alleman, Research Technician

M. Heben, Research Associate

Y. Xiao, Graduate Co-op

T. Bekkedahl, Undergraduate Student

J. McCullough, Graduate Student

C. Moore, Research Associate

T. Wang, Postdoctoral Scientist 


\section{Objectives}

The main objectives of the Crystal Growth Research Group are (1) to investigate alternative approaches for thin-layer silicon growth that could be used in multi-light-pass PV device structures, (2) to study procedures for growing high-quality silicon via float zone or other techniques suitable for PV application, (3) to re-establish a baseline silicon PV cell fabrication process to complement and support our experimental silicon materials work, and (4) to develop procedures and an apparatus for growing stoichiometric CuInSe2 crystals with 1-cm grain sizes that are of suitable quality for basic characterization and use by other researchers.

The work is funded by the PV Program.

\section{Key Accomplishments}

1. We improved our ability to measure minority-carrier lifetime on heavily doped $(0.3 \Omega-\mathrm{cm})$ wafers with the reflected microwave technique by moving a strobe light source into the enclosure of the wafer-tau system. The wafer-tau built-in laser light source is not intense enough to generate sufficient carriers to allow the detection of conductivity changes in this heavily doped material.

2. The Crystal Growth Research Group's work on porous silicon mostly studied posthydrogenation effects. We observed that, for some porous silicon samples, the photoluminescence intensity after remote-plasma rehydrogenation can be 25 times greater than that of the as-grown sample. In addition, the emission band is narrower and is centered more toward the blue for the remote-plasma processed sample.

3. Thin-layer $(-20 \mu \mathrm{m})$ Si films grown on (111) single-crystal Czochralski Si substrates from $\mathrm{Cu}-19 \% \mathrm{Si}$ solution at $910^{\circ} \mathrm{C}$ were evaluated via diagnostic solar cell fabrication. We observed efficiencies as high as $9.7 \%$ for $1-\mathrm{cm}^{2}$ cells that were not antireflective (AR) coated. After AR coating, this value increased to $14.1 \%$. The corresponding values for similar Czochralski-grown control wafers with no solution-grown film were $10.4 \%$ (not AR-coated) and $14.8 \%$. Although there is probably significant substrate contribution to the $14.1 \%$ cell performance, it is evident that the film growth process does not substantially degrade solar cell performance. Note that we did not perform high-temperature recrystallization of the solution-grown films. No temperatures above $950^{\circ} \mathrm{C}$ were employed.

4. We began a study of the effects of adding porous Si to the top surface of crystalline Si PV cells. Initial porous Si etching on a back-contact cell showed a slight improvement in the longer-wavelength side of the photocurrent spectrum and a degradation in the shorter-wavelength side of the spectrum and in the open-circuit voltage $\left(\mathrm{V}_{\mathrm{oc}}\right)$. The improvement in the longer-wavelength photoresponse is probably due to the light-trapping effect of the porous Si layer. Possible reasons for the shorter-wavelength photoresponse and $V_{o c}$ degradations include (1) blue light absorption by the porous Si layer (the sample surface has visible photoluminescence), (2) damage to the surface $\mathrm{n}^{+}$layer resulting from porous Si etching, and (3) reduced effectiveness of front surface passivation by porous $\mathrm{Si}$ (compared to the original $\mathrm{SiO}_{2}$ passivation).

\section{Publications}

1. T. F. Ciszek, T. H. Wang, R. W. Burrows, and $\mathrm{X}$. Wu, "Growth of thin crystalline silicon layers for photovoltaic device use," to be published in the Journal of Crystal Growth 128 (1993), pp. 314-318.

2. T. F. Ciszek, R. W. Burrows, T. H. Wang, and J. Alleman, "Growth and properties of thin crystalline silicon layers," 11th Photovoltaic Advanced Research and Development Project Review Meeting, May 13-15, 1992, Denver, American Institute of Physics Conference Proceedings 268 (1992), p. 75 . 
3. C. R. Schwerdtfeger and T. F. Ciszek, "Large-grained copper indium diselenide crystal growth by computer controlled high-pressure LEDS," 11th Photovoltaic Advanced Research and Development Project Review Meeting, May 13-15, 1992, Denver, American Institute of Physics Conference Proceedings 268 (1992), p. 200.

4. T. F. Ciszek, T. H. Wang, R. W. Burrows, and $\mathrm{X}$. Wu, "High-temperature solution growth of thin crystalline silicon layers," Proc. 11th EuropeanCommunity Photovoltaic Solar Energy Conference, Montreaux, Switzerland, October 12-16 (1992), pp. 423-426.

5. M. J. Heben, Y. Xiao, J. M . McCullough, Y. S. Tsuo, J. I. Pankove, and S. K. Deb, "Photoluminescence properties of porous silicon," American Institute of Physics Conference Proceedings 268 (1992), pp. 421-427.

6. Y. S. Tsuo, M. J. Heben, X. Wu, Y. Xiao, C. A. Moore, P. Verlinden, and S. K. Deb, "Photovoltaic device applications of porous silicon," Materials Research Society Proceedings 283 (1992), pp. 405-410.

7. Y. Xiao, M. J. Heben, J. I. Pankove, and Y. S. Tsuo, "Properties of porous silicon with photoluminescence enhanced by a remote-plasma treatment," Materials Research Society Proceedings 283 (1992), pp. 317-322.

8. M. J. Heben and Y. S. Tsuo, "Photoconductivity and carrier transport in porous silicon," Materials Research Society Proceedings $\mathbf{2 8 3}$ (1992), pp. 353-358.

9. Werner Luft and Y. Simon Tsuo, Hydrogenated Amorphous Silicon Alloy Deposition Processes, Marcel Dekker, Inc., New York, May 1993.

10. David W. Niles, Art J. Nelson, C. R. Schwerdtfeger, Hartmut Hochst, and Dennis Rioux, "Mo and Ni Schottky barriers to CuInSe2(112)," Advanced Metallization and Processing for Semiconductor Devices and Circuits-II 260 (1992).
11. C. R. Schwerdtfeger, and T. F. Ciszek, "Large-grained copper indium diselenide crystal growth by computercontrolled high-pressure liquidencapsulated directional solidification," American Institute of Physics Conference Proceedings 268 (1992).

\section{Amorphous Silicon Research}

\section{Investigators}

R. Crandall, Principal Investigator

B. von Roedern, Project Coordinator

H. Mahan, Senior Scientist

H. Branz, Senior Scientist

T. McMahon, Senior Scientist

B. Nelson, Staff Scientist

S. Salamon, Associate Engineer

Y. Xu, Associate Scientist

E. Iwaniczko, Research Technician

E. Molenbroek, Graduate Student

D. Tanenbaum, Graduate Student

\section{Objectives}

During FY 1992, the Amorphous Silicon Research Group emphasized four areas of research: (1) improving deposition methods of hydrogenated amorphous silicon (a-Si:H) and its alloys, (2) reducing the light-induced degradation of a-Si:H, (3) characterizing the resulting materials through measurements on films and devices from in-house work and university and industrials laboratories, and (4) modifying the research facilities to meet new NREL Environment, Safety, and Health requirements.

The work is funded by the PV Program.

\section{Key Accomplishments}

1. The deposition of a-Si:H using concentrated silane was stopped at the beginning of May 1991 for safety reasons in the existing NREL laboratories in Building 16. To restart deposition from concentrated silane, the activity was moved to the Joyce Street leased facility. The entire deposition system was redesigned, and a new safety analysis review (SAR) was prepared. Facility modifications, as well as deposition equipment 
modifications, were required and implemented to meet safety requirements. A major portion of the construction was completed at the end of FY 1992.

2. Our understanding of the light-induced metastable defects continued to improve. With more understanding, we find that the phenomenon is more complex. However, we are refining our models and experiments to restrict the number of possible causes of the degradation. We have shown unambiguously that the metastable effects are caused by charge trapping defects. This has important consequences for solar cell behavior.

3. Surface analysis techniques, including scanning Auger microscopy, X-ray photoelectron spectroscopy, secondary ion mass spectrometry, electron energy loss spectroscopy, and scanning tunneling microscopy were used in the investigation of the chemical and compositional properties, as well as the electronic structure, of amorphous silicon materials and devices.

4. A workshop on Amorphous Silicon Solar Cell Modeling was held on July 28-29, 1992, at NREL. It was attended by 22 researchers representing seven universities and three industrial companies. The workshop increased the interest of the attendees to work with the Analysis of Micro-Electronic and Photonic Structures (AMPS) model developed by Pennsylvania State University. Researchers can now use the model by arrangement with the university.

\section{Publications}

1. R. S. Crandall, B. P Nelson, P. D. Moskowitz, and V. M. Fthenakis, Safety Analysis Report for the Use of Hazardous Production Materials in Photovoltaic Applications at the National Renewable Energy Laboratory, NREL/MP-451-4778A, NREL, Golden, CO., 1992.

2. R. S. Crandall, in "Photovoltaic Advanced Research \& Development Project," edited by R. Noufi, American
Institute of Physics Conference Proceedings 268 (1992).

3. M. Vanecek, A. H. Mahan, B. P. Nelson, and R. S. Crandall, "Influence of hydrogen and microstructure on increased stability of amorphous silicon," in Proceedings of the 11th European Photovoltaic Solar Energy Conference, edited by Harwood Acad. Publ., Montreaux, Switzerland, 1992. p. 96.

4. T. J. McMahon, "Defect equilibration and stabilization -in low-spin-density a-Si:H," Phys. Rev. 45 (1992), p. 4512.

5. T. J. McMahon and M. S. Bennett, "Film morphology, excess shunt current and stability in triple-junction cells," presented at the MRS Spring Meeting, 1991, San Francisco, CA.

6. T. J. McMahon, "Defect equilibration and stabilization in two types of lowspin-density a-Si:H," presented at the MRS Spring Meeting, 1992, San Francisco, CA.

7. H. M. Branz, S. E. Asher, and B. P. Nelson, "Trap-controlled hydrogen diffusion and the mechanism of lightenhanced diffusion in a-Si:H," in Amorphous Silicon Technology - 1992, edited by $M$. J. Thompson, Y. Hamakawa,. P. G. LeComber, A. Madan, and E. A. Schiff, Materials Research Society, Pittsburgh, PA., 1992, p. 431.

8. H. M. Branz and E. Iwaniczko, "Observation of metastability in amorphous silicon containing 0.1 at.\% hydrogen," in Amorphous Silicon Technology - 1992, edited by M. J. Thompson, Y. Hamakawa, P. G. LeComber, A. Madan, and E. A. Schiff, Materials Research Society, Pittsburgh, PA., 1992, p. 389.

9. A. Yelon, B. Movaghar, and H. M. Branz, "Origin and consequences of the compensation (Meyer-Neldel) law," Phys. Rev. B46 (1992), p. 12244. 


\section{III-V High-Efficiency Photovoltaic Cells}

\section{Investigators}

J. Olson, Principal Scientist

S. Kurtz, Senior Scientist

K. Bertness, Staff Scientist

A. Kibbler, Staff Scientist

D. Friedman, Staff Scientist

C. Kramer, Research Technician

D. Arent, Postdoctoral Scientist

G. Guist, Summer Student

\section{Objectives}

The group's objectives are (1) to use metalorganic chemical vapor deposition (MOCVD) to fabricate III-V semiconductor materials such as GaAs, GaP, InP, GaInP, and $\mathrm{AlGaAs}$ appropriate to high-efficiency solar cell applications; (2) to develop a fundamental understanding of the materials and their method of growth; (3) to develop an understanding of, and solutions to, the problems inherent in the fabrication of highefficiency, multijunction cascade solar cells using these materials; and (4) to complete the corrections to the MOCVD equipment to meet new NREL Environment, Safety, and Health regulations.

The work is funded by the PV Program and the Materials Science Division of OER/BES. There is also funding from industrial partners in Work for Others programs.

\section{Key Accomplishments}

1. We observed for the first time CuPttype ordering in Ga0.5 In $0.5 \mathrm{As}$ and $\mathrm{Al}_{0.5}$ In0.5As (on InP). The ordering was observed by transmission electron diffraction, and the concomitant red shift of the band-gap energy was measured by photocurrent spectroscopy. The band-gap shift for Ga0.5In0.5As with growth temperature and rate is analogous to that seen for $\mathrm{Ga}_{0.5} \operatorname{In}_{0.5} \mathrm{P}$, suggesting that the ordering dynamics are similar.

2. The band-gap shifts of both Ga0.5In0.5As and $A l_{0.5} \operatorname{In}_{0.5}$ As reach a maximum at a growth temperature of about $550^{\circ} \mathrm{C}, 100^{\circ} \mathrm{C}$ lower than that for Ga0.5In 0.5 P. In addition, the band gaps decrease in a similar manner as the group $\mathrm{V}$ overpressure is increased. These results imply that (1) the (Al)Ga-In interaction that promotes ordering is modulated by the chemistry of the interposed group $V$ atom, and (2) a group $V$ terminated surface is a "necessity" for the growth of the ordered surface structure for both the arsenides and phosphides.

3. At the Molecular Beam Epitaxy (MBE) facility of Bell Northern Research, in Ottawa, Canada, we grew a series of $(\mathrm{A} 1 \mathrm{As})_{\mathrm{n}}(\mathrm{GaAs})_{\mathrm{m}}$ perfectly and imperfectly ordered superlattices and a AlGaAs bulk (unordered) alloy on (100) GaAs. The band-gap energies confirm the results of Sasaki et al. and show that the band gap of a disordered $\mathrm{CuAu}$-like superlattice is lower than that of the random binary alloy or the ordered $(2,2)$ superlattice. This supports the idea that these pseudoperiodic structures may serve as prototypes for imperfect spontaneously ordered alloys.

4. On May 11, a year and one day after the suspension of toxic-gas activities at NREL, the growth system in Laboratory 103 completed its first run without incident. Approval of the Operational Readiness Review (ORR) panel for conditional restart was given on May 6, toxic gases were delivered on May 7, and gases were installed on May 8. This growth system was the first one to complete the ORR and resume the use of toxic gases.

5. Significant progress was made in growing device-quality aluminumcontaining material in laboratory $16 / 103$ for our tandem solar cell device, resulting in the fabrication of a $\mathrm{GaInP}_{2}$ cell with an efficiency of $8.9 \%$ before the application of an AR coating. The photocurrent in this cell is down by $-15 \%$ from the cell current in our $27.3 \%$ (one sun, air mass 1.5 ) tandem cell. The source of the difficulties seems to be partially oxidized organometallic compounds in the reactor fittings. This contamination was probably aggravated by the long downtime associated with the 
suspension of toxic gas use. Secondary ion mass spectrometry (SIMS) results from S. Asher were instrumental in identifying the source of the contamination.

6. The ORR was completed, and approval was given in September for restarting the MOCVD reactor in Laboratory 368.

\section{Publications}

1. D. J. Arent, K. A. Bertness, M. Bode, S. R. Kurtz, and J. M. Olson, "Band gap narrowing in ordered $\mathrm{Ga}_{0.47} \operatorname{In}_{0.53} \mathrm{As}$," Appl. Phys. Lett. (in press).

2. S. R. Kurtz, J. M. Olson, A. E. Kibbler, and S. Asher, "Model for incorporation of zinc in MOCVD growth of Ga0.5In $0.5 \mathrm{P}, "$ Proceedings of the InP and Related Materials Conference, IEEE, New York, New York, 1992.

3. D. J. Mowbray, R. A. Hogg, M. S. Skolnick, M. C. Delong, S. R. Kurtz, and J. M. Olson, "Valence-band splitting in ordered Ga0.5 $\operatorname{In}_{0.5} \mathrm{P}$ measured by polarized photoluminescence excitation spectroscopy," Phys. Rev. B.-Condensed Matter 46 (1992), pp. 7232-7235.

4. S. R. Kurtz, J. M. Olson, A. E. Kibbler, and K. A. Bertness, "Incorporation of zinc in MOCVD growth of Ga0.5In0.5P," J. Cryst. Growth 124 (1992), pp. 463-469.

\section{Solid-State Theory}

\section{Investigators}

A. Zunger, Research Fellow

S. Froyen, Senior Scientist

S.-H. Wei, Senior Scientist

R. Osorio, DDF Senior Research Associate

D. Laks, OER/BES Postdoctoral Scientist

Z. W. Lu, OER/BES Postdoctoral Scientist

C. -Y. Yeh, OER/BES Scientist

S. Zhang, OER/BES Research Associate

\section{Objectives}

The Solid-State Theory Group's primary objective is to capitalize on recent developments to (1) bring the state-of-the art methods and ideas of condensed matter theory into the realm of PV materials, (2) develop a fundamental understanding of the elements that constitute and enhance solar cell performance, and (3) use this knowledge to design novel PV materials that could be grown and tested in the laboratory by modern crystal growth techniques.

A second objective of the group is to analyze the properties of existing materials. A goal of this research is to ensure that PV technology continuously benefits from breakthroughs achieved in other areas of condensed matter physics. This approach supplements the more conventional trialand-error approaches for designing PV materials.

The work is funded by the PV Program and the Materials Science Division of OER/BES.

\section{Key Accomplishments}

1. A complete theory of phase stability was developed. It shows that relativistic effects are responsible for the phase selectivity in Ni-Au, Ni-Pt, and Pt-Au. This is the first demonstration of the crucial effects of relativity in solid-state structural selectivity. See Publications 10-13.

2. A new cluster expansion has been developed and tested. It overcomes the difficulties experienced with previous approaches when applied to longperiod superlattices. It opens the way for calculating the thermodynamic properties of size-mismatched alloys. See Publication 11.

3. Our new theoretical work has explained how interfacial roughness dramatically affects the optical properties and thermodynamic properties of semiconductor superlattices. For example, the conduction band minimum changes from $L_{1} c$ to $X_{1} c$ in AlAs/GaAs short-period superlattices. See Publication 2. 
4. Recent advances in crystallography have resulted in significantly more accurate determinations of electronic charge distribution than previously possible. We have applied our highly accurate implementation of the density functional theory to these systems, with excellent agreement for those structure factors that were directly measured (our $\mathrm{R}$-factor is $\sim 3$ times better than previous ones). This clarifies the bonding mechanisms in $\mathrm{C}, \mathrm{Si}, \mathrm{Ge}$, and NiAl. See Publication 7.

5. We have calculated the total energy of formation of the zincblende (ZB) versus the Wurtzite $(W)$ structure for many semiconductors. The results show a strong correlation with the "atomic orbital radii" developed in 1980 by A. Zunger. The correlation is so good that one can predict from it the ZB-W energy difference in any binary semiconductor. See Publications 8, 9.

6. Heterojunction band offsets were determined for many III-V semiconductor pairs, and the effects of strain on band lineups were predicted. See Publication 1.

7. MnTe can be grown epitaxially in the ZB structure. Neutron diffraction reveals that, below a temperature $T_{N}$, the $\mathrm{Mn}$ spins order in a chalcopyrite form. Local spin density (LSD) total energy calculations, coupled with solutions to the spin-5/2 Heisenberg Hamiltonian, were used to search for the stable ordered spin configuration. We found the correct chalcopyrite order. The over-estimation of $\mathrm{T}_{\mathrm{N}}$ was traced to the fact that the $\mathrm{Mn} d \mathrm{band}$ energy is too low in the LSD description. Increasing its binding energy leads to the correct value of $\mathrm{T}_{\mathrm{N}}$, as well as to agreement with photoemission data on the exchange splittings. See Publication 3.

8. Recently, the ZB semiconductor alloy $\mathrm{Cd}_{1-\mathrm{x}} \mathrm{Zn}_{\mathrm{x}} \mathrm{Te}$ was found to exhibit ferroelectricity, suggesting that the electric dipoles are ordered in this otherwise random alloy. It was previously suggested that the development of a dipole (which is symmetry-forbidden in the $\mathrm{ZB}$ structure) must signal an off-center displacement of atoms in the structure. To establish the physical origins of order-inducing off-center atomic displacements, we have studied the stability of $\mathrm{CdTe}, \mathrm{GaAs}$, and $\mathrm{CuCl}$ with respect to such deformations. We predict that $\mathrm{CuCl}$ must exhibit such an off-center metastability, analogous to the DX-center in Si-doped GaAlAs. This explains the hitherto mysterious double phonon lines seen in $\mathrm{CuCl}$. We have established the controlling physical mechanism of such off-center displacements: it is a pseudo JahnTeller effect. This work identifies the origins of dipole ordering in $\mathrm{ZB}$ compounds. See Publication 4.

9. We achieved a breakthrough in the theory of ordering. Any physical property $P$ of the imperfectly ordered alloy can be related to the property $P(\eta=0)$ of the random structure and the property $P(\eta=1)$ of the fully ordered structure, by

$$
P(\eta)=P(0)+\eta^{2}[P(1)-P(0)]
$$

This general equation is of potential wide application in statistical mechanics of alloys. We used it, for the first time, to deduce quantitative order parameters for Ga0.5 $\operatorname{In}_{0.5}$ P. See Publications 14,15 .

10. We developed a truncated crystal approach for $\mathrm{Si}$ wires in which one calculates the optical gaps of the wire from a bulk band structure by requiring that the wave functions vanish at the wire boundaries. Our calculation provides the magnitude of the Si wire band gap as a function of (1) the width of the wire ( $\mathrm{n} \times \mathrm{m}$ monolayer across) and (2) the orientation of the wire faces. For (001)-oriented wires, the indirect gap equals the direct gap for the smallest $4 \times 4$ wire. The gap then drops rapidly from 4.5 to $1.2 \mathrm{eV}$ as $(n, m)$ increases. The pseudo direct gap is slightly higher than the indirect gap; however, the direct gap is larger than both (except for a $4 \times 4$ wire). The direct gap for (110) wires is lower than the direct gap for (001) wires, but in both cases the indirect gap is lower. 
11. First-principles phase diagrams were determined for the first time for nonisovalent alloys, such as GaAs-Ge (see Publication 5) and CuInSe2-ZnSe (see Publication 6).

12. The mechanisms were spontaneous ordering in III-V alloys and were traced to surface reconstruction (see Publication 16) and epitaxial (see Publication 17) effects.

13. We held a review meeting on research opportunities in photovoltaics. A special issue of the Journal of Electronic Materials details the recommendations of the 17-member panel. See Publication 18.

\section{Publications (Asterisks denote partial} support by BES/OER).

\section{Band Offsets:}

1. R. G. Dandrea, C. B. Duke, and A. Zunger, "Interfacial atomic structure and band offsets at semiconductor heterojunctions," J. Vac. Sci. Technol. 10B (1992), pp. 1744-1753.

\section{Disorder Effects in Semiconductors:}

2. D. B. Laks and A. Zunger, "Identity of conduction band minimum in (AlAs) 1 (GaAs) 1 superlattices: Intermixing-induced reversal of states," Phys. Rev. B.-Rapid Communication 45 (1992), pp. 11411-11414.*

3. S.-H. Wei and A. Zunger, "Electronic origins of the magnetic phase transitions in zincblende $\mathrm{Mn}$ chalcogenides," submitted for publication to Phys. Rev. $B$.

4. S.-H. Wei, S. B. Zhang, and A. Zunger, "Off-center atomic displacements in zincblende semiconductors," Phys. Rev. Lett. 70 (1993), p.1639.*

5. R. Osorio and S. Froyen, "Interaction parameters and a quenched-disorder phase diagram for (GaAs) $1-x \mathrm{Ge}_{2 \mathrm{x}}$ alloys," Phys. Rev. B47 (1993), p. 1889.

6. R. Osorio, Z. W. Lu, S.-H. Wei, and A. Zunger, "First-principles phase diagram of pseudoternary chalcopyrite-zincblende alloys," Phys. Rev. B.-Rapid Communication 47 (1993), p. 9985.

\section{Accurate Electronic Charge Densities:}

7. Z.W. Lu, A. Zunger, and M. Deutsch, "The electronic charge distribution in diamond, silicon and germanium," Phys. Rev. B47 (1993), p. 9385.*

\section{Wurtzite-Zincblende Polytypism:}

8. C. Y. Yeh, Z. W. Lu, S. Froyen, and A. Zunger, "Predictions and systematizations of the zincblende-Wurtzite structural energies in binary octet compounds," Phys. Rev. B Rapid 'Communication 45, (1992) pp. 1213012133.*

9. C. Y. Yeh, Z. W. Lu, S. Froyen, and A. Zunger, "The zincblende-Wurtzite polytypism in semiconductors," Phys. Rev. B46 (1992), pp. 10086-10097.*

\section{Phase Stability in Metallic Alloys:}

10. Z. W. Lu, S.-H. Wei, and A. Zunger, "Relativity-induced ordering and phaseseparation in intermetallic compounds," Europhy. Lett. 21(1993), p. 221.*

11. D. B. Laks, L. G. Ferreira, S. Froyen, and $A$. Zunger, "An efficient cluster expansion for substitutional systems," Phys. Rev. B 46 (1992), pp. 12587 12605.*

12. A. Zunger, "First principles statistical mechanics of semiconductor alloys and intermetallic compounds," to appear in NATO Advanced Study Institute on Statics and Dynamics of Alloys.*

13. Z. W. Lu, S.-H. Wei, and A. Zunger, "Comment on origins of compositional order in NiPt alloys," Phys. Rev. Lett. 68 (1992), p. 1961.* 


\section{Spontaneous Ordering Effects in Semiconductors:}

14. D. B. Laks, S.-H. Wei, and A. Zunger, "Evolution of alloy properties with long-range order," Phys. Rev. Lett. 69 (1992), p. 3766.*

15. S.-H. Wei, D. B. Laks, and A. Zunger, "Dependence of the optical properties of semiconductor alloys on the degree of long range order," Appl. Phys. Lett. 62 (1993), p. 1937.

16. S. Froyen, J. E. Bernard, R. Osorio, and A. Zunger, "Surface energetics and ordering in CaInP," Physica Scripta T45 (1992), p. 272.

17. A. Zunger "Structural effects in coherent epitaxial semiconductor films," to appear in Handbook of Crystal Growth 3, North Holland Publications.

18. A. Zunger, S. Wagner, and P. M. Petroff, "New Materials and Structures for Photovoltaics," J. Elect. Mater. 22 (1993), pp. 3-16.

\section{Solid-State Spectroscopy}

\section{Investigators}
A. Mascarenhas, Senior Scientist
R. Alonso, Postdoctoral Scientist
G. S. Horner, Graduate Student

\section{Objectives}

The objectives of solid-state spectroscopy research are (1) to obtain an understanding of the fundamental opto-electronic properties of solid-state materials used for PV applications, (2) to interact with deviceoriented research to help apply this information to help improve the performance of the devices, and (3) to explore the optical properties of novel semiconductor architectures that have potential for PV applications.

\section{Key Accomplishments}

1. The optical techniques described under "objectives" gave the first experimental evidence for the fact that the phenomenon of spontaneous ordering in $\mathrm{GaInP}_{2}$ is not in the form of perfectly ordered domains $(\eta=1)$ distributed in a matrix of the perfectly random alloy $(\eta=0)$, as had been previously thought. Rather, it is a distribution of domains for which the variation of the order parameter $\eta$ between 0 and 1 is governed by a statistical distribution function $F(\eta)$. The proof comes from the following facts:

- Ordered samples have a photoluminescence excitation spectroscopy (PLE) absorption edge that is softer, more polarization dependent, and blue shifted further from the PL peak than that of less ordered samples.

- The PZ modulated spectra showed only a single set of critical points $\left(E_{g}, E_{g}+\Delta_{c}\right.$, and $\left.E_{g}+\Delta_{S O}\right)$ for any given sample, which is consistent with a statistical distribution $F(\eta)$ of domains with order parameter that is peaked at some value $\eta_{\mathrm{p}}$.

- The crystal-field splitting measured from both the PL and PZ spectra correlates with the band-gap lowering (and hence order parameter $\left.\eta_{p}\right)$.

2. We completed an experimental setup for resonance raman scattering experiments and have started the raman scattering experiments, as listed above, in the optical phonon region, and we intend to extend this to the acoustic phonon region.

3. We developed a theoretical model for the $(\mathrm{GaP})_{2} /(\mathrm{InP})_{2}$ superlattices grown at the University of Illinois, Urbana. We used an $8 \times 8$ Luttinger-Hamiltonian, which included the effects of coherency strain generated by the lateral composition modulation, to analyze our experimental results reported in FY 1991. These studies had yielded the first experimental evidence for a 
spontaneously generated "effective mass lateral superlattice." The situation elucidated by our calculations illustrates a new quantum regime in which there are no confining potentials. It is the modulation of the group velocity of Bloch states manifested as a modulation of the effective mass, rather than band-gap modulation, that gives rise to a superlattice effect.

\section{Publications}

1. A. Mascarenhas, R. G. Alonso, G. S. Horner, and K. Y. Cheng, "Experimental evidence for spontaneously generated effective mass lateral superlattices," Superlatt. \& Microstruct. 12 (1992), pp. 57-61.

2. A. Mascarenhas, R. G. Alonso, S. Froyen, and G. Horner, "Spontaneously generated effective mass lateral superlattices," accepted for publication in Phys. Rev. B.

3. R. G. Alonso and A. Mascarenhas, "Quantum well solution using a multiband transfer matrix approach," submitted to Journal of Computational Physics.

4. G. S. Horner, A. Mascarenhas, S. Froyen, R. G. Alonso, K. Bertness, and J. M. Olson, "Photoluminescence excitation spectroscopy studies in spontaneously ordered $\mathrm{GaInP}_{2}$," Phys. Rev. B47 (1993), p. 4041.

5. R. G. Alonso, A. Mascarenhas, S. Froyen, G. S. Horner, K. Bertness, and J. M. Olson, "Piezo-modulated reflectance studies in spontaneously ordered $\mathrm{GaInP}_{2}$," Solid State Communications, 85(12) (1993), pp. 1021-1024.

\section{Program Management}

\section{Managers}

John Benner, Senior Project Manager Holly Thomas, Project Coordinator

\section{Objectives}

The primary objective of the Crystalline Materials and Advanced Concepts Project is to support internal and subcontracted research for advancing high-efficiency photovoltaics. The project provides technical assistance, process development, and analysis to assist industry in increasing the performance of current crystalline silicon and $\mathrm{GaAs}$ concentrator cell products. It supports applied research on advanced technologies that can be developed into future products with substantially higher efficiencies. The project also devotes substantial resources to the basic science and supporting research activities needed to assure the continuous improvement of PV technology. The University Participation and New Ideas Programs are included in this latter function.

The University Participation Program provides a unique forum to extract guidance from the academic community. Through the peer review and selection process, key issues in photovoltaics are identified in an environment free of goals-oriented program influences. The projects selected for award receive three-year commitments to assure continuity of support for the students through their theses, and to minimize external interference.

The New Ideas Program serves to collect proposals for novel concepts in solar electric conversion to competitively select projects outside of the mainstream of PV program research that have the potential of changing the overall program direction if the objectives can be achieved

The program management activity also serves to coordinate NREL's terrestrial energy conversion research with the Department of Defense (DoD) and NASA programs. During FY 1992, NREL's aerospace energy programs supported research ranging from advanced PV cells to the exploration of lunar resource recovery technology.

\section{Publications}

1. J. P. Benner, J. M. Olson, and T. J. Coutts, "Recent advances in highefficiency solar cells," Advances in Solar Energy 7 (1992), pp. 125-165. 


\begin{tabular}{|c|c|c|c|}
\hline $\begin{array}{c}\text { Document Control } \\
\text { Page }\end{array}$ & $\begin{array}{l}\text { 1. NREL Report No. } \\
\text { NREL/TP-451-5733 }\end{array}$ & $\begin{array}{l}\text { 2. NTIS Accession No. } \\
\text { DE94000204 }\end{array}$ & 3. Recipient's Accession No. \\
\hline \multirow{2}{*}{\multicolumn{3}{|c|}{$\begin{array}{l}\text { 4. Title and Subtitle } \\
\text { Annual Report, Materials Science Branch, FY } 1992\end{array}$}} & $\begin{array}{l}\text { 5. Publication Date } \\
\text { October } 1993\end{array}$ \\
\hline & & & 6. \\
\hline \multicolumn{3}{|c|}{$\begin{array}{l}\text { 7. Author(s) } \\
\text { Materials Science Branch }\end{array}$} & 8. Performing Organization Rept. No. \\
\hline $\begin{array}{l}\text { 9. Performing Organizat } \\
\text { National Renewable E }\end{array}$ & $\begin{array}{l}\text { Name and Address } \\
\text { rgy Laboratory }\end{array}$ & & $\begin{array}{l}\text { 10. Project/TaskWork Unit No. } \\
\text { PV314001 }\end{array}$ \\
\hline \multicolumn{2}{|c|}{$\begin{array}{l}\text { National Renewable Energy Laboratory } \\
1617 \text { Cole Blvd. } \\
\text { Golden, Colorado } 80401-3393\end{array}$} & & $\begin{array}{l}\text { 11. Contract (C) or Grant (G) No. } \\
\text { (C) } \\
\text { (G) }\end{array}$ \\
\hline \multirow{2}{*}{\multicolumn{3}{|c|}{ 12. Sponsoring Organization Name and Address }} & $\begin{array}{l}\text { 13. Type of Report \& Period Covered } \\
\text { Progress Report }\end{array}$ \\
\hline & & & 14. \\
\hline
\end{tabular}

15. Supplementary Notes

16. Abstract (Limit: 200 words)

This report summarizes the progress of the Materials Science Branch of the National Renewable Energy Laboratory (NREL) from October 1, 1991, through September 30, 1992. Six technical sections of the report cover these main areas of NREL's inhouse research: Crystal Growth, Amorphous Silicon, III-V High-Efficiency Photovoltaic Cells, Solid State Theory, Solid State Spectroscopy, and.Program Management. Each section explains the purpose and major accomplishments of the work in the context of the U.S. Department of Energy's National Photovoltaic Research Program plans.

17. Document Analysis
a. Descriptors
annual report ; research and development ; photovoltaics ; solar cells ; materials science
b. Identifiers/Open-Ended Terms
c. UC Categories
270

18. Availability Statement

National Technical Information Service

19. No. of Pages

U.S. Department of Commerce

15

5285 Port Royal Road

Springfield, VA 22161

20. Price

$\mathrm{A03}$

Form No. 0069E (6-30-87) 